\title{
Informational Interaction of Authorities with Business Entities and Population: the Administrative Model and Big Data Analysis
}

\author{
L. Bushueva. \\ Management and Entrepreneurship Institute \\ Syktyvkar State University named after Pitirim Sorokin \\ Syktyvkar, Russia
}

\author{
Yu. Popova \\ Management and Marketing Department \\ Syktyvkar State University named after Pitirim Sorokin \\ Syktyvkar, Russia
}

\begin{abstract}
The article deals with the model of informational interaction between all subjects of the public administration system (between authorities and business entities, population and civil society) with application of new technologies for big data processing and analysis. The model includes conception, mechanisms and organizational structure of administration. In assessment of the interaction effectiveness you are invited to consider its economic, strategic and social dimensions and to determine features of the information environment functioning. The application of new technologies for Big Data processing and analysis will allow to lower ambiguity and to improve adaptedness of the public administration system in present problem solving and new governance challenges definition.
\end{abstract}

Keywords - Big Data, informational interaction, information sphere, informational interaction effectiveness in the territory, the administrative model of informational interaction

\section{INTRODUCTION}

Advances in information and communication systems and technologies and better opportunities for data processing and analysis have led to reinforced information support of decision making processes at all levels of administrative hierarchy, primarily on the state authority level. Information and communication technology (ICT) contributes to higher effectiveness of informational interaction between government authorities, business entities and population. In today's conditions their development is accompanied by changes in their content, forms, organizational structures, methods and administrative models for governmental interaction with all stakeholders. Efforts are taken in several areas of focus, for instance, establishment of information technology centers, multifunctional centers for business entities and the public, Population Register, etc.

Prospects of introduction of state monitoring, control and administration technology based on the Big Data analysis are under discussion. It will allow to process unstructured data array in real time and therefore will reduce uncertainty and improve adaptedness of the public administration system to the ever changing environment.

Provision of digital state services and, transition to registers generate new structured and unstructured user data that are necessary to be stored, processed and used to tackle challenges in information interaction between authorities and public. It is not possible to process such huge volumes of ever updating data with traditional methods and techniques, which eventually implies integration of the Big Data analysis methods in the administrative models of informational interaction $[1,4,7,9,11,13]$. That will make it possible to identify the needs of individuals and the public in state services, determine a user profile, examine the feedback of certain social groups to the action performed, consider public opinion about particular issues of social and economic policy, monitor relevance of state services, etc.

There are a lot of definitions of administrative models that include a number of parameters that allow classifying and comparing them $[3,5,8,10,12,14,15,16,17,18]$. However, despite significant results in the development of theory and practice, many theoretic and methodological aspects of development of administrative business models for informational interaction between authorities and all stakeholders remain unsolved.

Development of up-to-date administrative models of informational interaction between authorities and business entities and the public is related to the advances in information and computer technologies that contribute to solving current administrative challenges and formulating new ones through the Big Data processing and analysis.

\section{ADMINISTRATIVE MODEL OF INFORMATIONAL}

\section{INTERACTION BETWEEN AUTHORITIES AND STAKEHOLDERS}

Improvement of authority-business-public interaction administration is a multifaceted problem, a complex process of searching new concepts, analytical tools, models and approaches to social project implementation.

We suggest having a detailed look at the components of the system of information interaction between authorities, business entities and the public that includes administrating entities and administrated objects, interaction administration concept, administrating mechanisms (executive, financial, resource, informational, infrastructural, etc.), organizational structure of administration.

State authorities (federal, regional and municipal), as well as the civil society, population, business community and 
others serve as information interaction administrating entities.

All of them provide an administrative impact on an administrated system to achieve an objective. The object in the system is something that is subject to the administrative impact, in other words it is development of the system of information interaction in the region aiming at the improvement of digital economy effectiveness. At the moment, regional authorities are adopting regulations to create conditions for the territory's information interaction development, however it is necessary to create means for better involvement of entities, organizations and civil society in the regional policy of heavier use of ICT in interaction of all administrating entities. There are various connections between administrating entities and administrated objects as part of the interaction administrating system that may be described with the help of the administrating model [2] which drives the administrating mechanism.

The integration of the administrative model of informational interaction and assessment of the overall information space will allow reflecting effectiveness of functioning of authority-business-public informational interaction objects in a particular environment. Fig. 1 shows consolidated groups of elements of the informational interaction administrating system:

- Concept of administration of interaction providing a definition for identity of the model elements, mission, vision, policy of regional partnerships based on the Big Data analysis results. There lots of various methods for Big Data analysis that are based on the tools borrowed from statistics and informatics. McKinsey report [9] provides classification of analyzing methods and techniques, including crowdsourcing, mixing and integration of data, artificial neural network, predictive analytics, statistical analysis, visualization of analytical data (pictures, diagrams, animation), etc.

- Mechanisms of administration as a combination of managerial decision taking procedures that describe executive and resource (including financial, informational, infrastructural, etc.) set of tools with regard to the development of the administrative system of interaction between authorities and the region. Executive tools ensure regulatory control of the administrative system of informational interaction. Provision of resources is primarily related to search of key sources of budgetary and nonbudgetary funding of developments and their implementation, including public contracts, grants for scientific research and development, prizes, etc.

- Organizational structure of administration. Currently, functions of administrating informational interaction between authorities, civil society and business entities in regions are assigned to regional operators for electronic government infrastructure security (information technology centers, multifunctional centers, etc.).

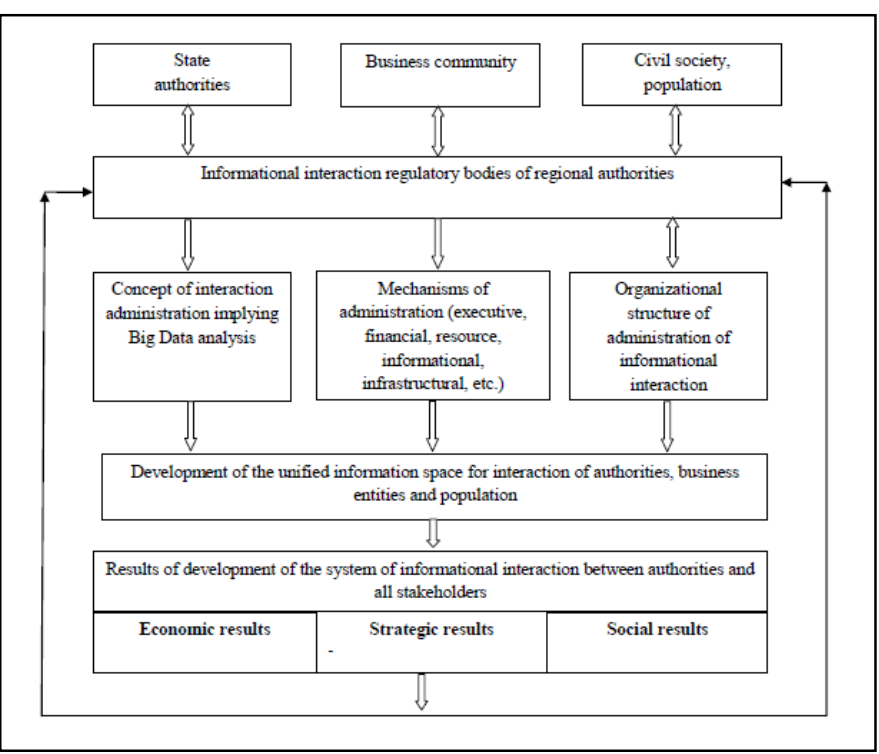

Fig. 1. Administrative model of informational interaction between authorities, business entities and population.

Development of the system of informational interaction between authorities, business entities and population has several stages:

1. Building of the system of informational interaction. This stage involves recognition of the existing need in developing of interaction, evaluation of potential stakeholders, drafting of scenarios and predicting of the level of value and effectiveness of interaction between administrating entities and administrated objects.

2. Establishment of authority-business-public informational interaction regulatory bodies.

3. Evaluation of results of development of the unified information space for interaction between authorities and the territory based on the system of indicators (including statistical ones) and application of new technologies for Big Data processing and analysis.

Evaluation of interaction administration effectiveness, including analysis of the strategic, economic and social aspects, is the least developed and the most debatable issue [6].

Economic effectiveness is defined by the benefits received by the partners in the interaction process. These include the economic results of the developed system of informational interaction between authorities and the territory: digital record, analysis and control of key industrial indicators and resources (material facilities, taxable assets, recipients of social aid, etc); reduction of time and financial expenditures of individuals and entities from interaction with governmental and municipal authorities; higher quality and accessibility of provided state and municipal services; access to resources, technologies, information, etc.

Among strategic results you should note comprehensive administration of the process of implementation of information and communication services in regions; development of information and communication infrastructure, and tightening of public control of the activities of regional and municipal authorities, etc. 
Social aspect of interaction is connected with the possibility to build trust-based, open and consequently more effective relations.

Key social results achieved through development of the system of informational interaction between authorities with the territory may include:

- building an effective feedback system for authorities' communication with entities and individuals;

- making information about the activities of state and municipal authorities more accessible for the population;

- higher level of trust between the participants of informational interaction; growing trust of population to authorities;

- user friendliness and convenience in using state and municipal services, faster service provision process.

Since the process of administration of informational interaction includes regulation of the information space (environment) for interaction between authorities, businesses and public, Fig. 2 demonstrates four main groups of characteristics (parameters) that allow analyzing its effectiveness [6]. They may have both a positive and a negative impact of the effectiveness of informational interaction between authorities, businesses and public.

\begin{tabular}{|c|c|}
\hline $\begin{array}{l}\text { Characteristics of functioning of } \\
\text { informational space institutions } \\
\text { Reflect effectiveness of formal and informal } \\
\text { institutions implemented - controlling and } \\
\text { coordinating bodies, regulations and rules for } \\
\text { interaction parties; infrastructure created as } \\
\text { part of their joint activity. }\end{array}$ & $\begin{array}{l}\text { Characteristics of functioning of } \\
\text { informational space infrastructure } \\
\text { Reflect effectiveness of functioning of } \\
\text { facilities and services, consulting and training } \\
\text { centers, research and development centers, } \\
\text { centers of network software, common data } \\
\text { bases, etc. }\end{array}$ \\
\hline \multicolumn{2}{|c|}{$\rightarrow-1}$, \\
\hline \multicolumn{2}{|c|}{$\begin{array}{l}\text { EFFECTIVENESS OF FUNCTIONING OF INFORMATIONAL } \\
\text { INTERACTION SPACE }\end{array}$} \\
\hline$=$ & $\square$ \\
\hline $\begin{array}{l}\text { Charac teristics of commuricative space of } \\
\text { informational interaction }\end{array}$ & $\begin{array}{l}\text { Functional and structural characteristics of } \\
\text { informational space of interaction }\end{array}$ \\
\hline $\begin{array}{l}\text { Describe the size of administrative distance } \\
\text { between parties of interaction, degree of } \\
\text { coordination of their activities and strategies, } \\
\text { openness, security, creativity and density of the } \\
\text { communication environment. }\end{array}$ & $\begin{array}{l}\text { Enable assessment of the size of space, its } \\
\text { stability, homogeneity, proportion, level of } \\
\text { interaction structuring. }\end{array}$ \\
\hline
\end{tabular}

Fig. 2. Parameters to evaluate effectiveness of functioning of the integrated information space for interaction between authorities and the territory.

Effective functioning of the information environment implies there are institutions regulating interaction between authorities and the region. "Rank parameters" may be formal or informal institutions. Formal institutions include controlling and coordinating bodies - joint administration teams, information technology centers, multifunctional centers, coordination councils, representative bodies, etc. The better if the interaction, the more influential they turn to be. Interaction institutions, including the system of normative and legal regulation, play a significant part in creating a uniform informational space, building relations between authorities, business entities and public, lobbying interests of all interaction stakeholders.

The most important informal institutions are rules of behavior for participants of the interaction which state moral and ethical standards and values reducing the level of opportunism and raising the level of trust.
Analysis of the institutions' operation is effected through expert assessment of effectiveness of controlling and coordinating bodies, compliance of interaction participants' behavior with the rules, standards and regulations, etc.

Functioning effectiveness of network infrastructure of the interaction space is determined by activities of jointly funded facilities, for example buildings or services required to ensure functioning of the information interaction administration system. They provide interaction participants with services such as research and development (jointly funded research and development centers), information and consulting services, training services in special training companies, training centers, etc.

Crucial elements of informational infrastructure are software, data bases used, mass media, social networks, and a powerful network server, with maintenance of the latter being the most important condition of effective cooperation.

Communication space ensuring coordination of interaction and speed of information exchange between administrated objects and administrating entities is a crucial aspect of the functioning effectiveness of information environment.

Key characteristics of communication network space are:

- Administrative distance that depends on the degree of contact intensity, transparency of interaction participants, and availability of collective administrating bodies;

Coordination level of the actions of interaction participants defined by the degree of alignment of actions and strategies as part of joint planning, interaction conventionalism level, promptness and accuracy of response to a partner's enquiries, degree of situation uncertainty and possibility to forecast change of the situation, ability to solve conflicts. The function of coordination is to consolidate autonomous participants of interaction.

The following is suggested to be referred to functional and structural characteristics of information space:

- $\quad$ Size and stability of information space measured as the number of objects and entities. Interaction stability is determined by its duration;

Structuring level defined by intensity and closeness of interaction, level of centralization, etc. Closeness (intensity) is determined through frequency of contacts of interaction participants within a particular time period. Information space centralization degree is defined by the presence of one or a number of administrating entities and by their impact on interaction development. Centralization degree, as a rule, grows when interaction functioning period increases. Structuring improves in the process of functioning of the administrating system for information interaction. It defines the degree of its orderliness and controllability.

\section{CONCLUSION}

The system of informational interaction between authorities and business entities and public is facing considerable changes under today's conditions of information and communication technology development.

The article offers the administrative model of informational interaction of authorities with all stakeholders, 
including its concept, mechanisms and organizational structure of administration.

The process of administration of informational interaction between authorities and business entities and public, according to the authors, includes administration of interaction and control of the environment of interaction. Therefore, it is suggested to analyze strategic, economic and social aspects of the interaction effectiveness, as well as to measure parameters of the information environment functioning, to assess its effectiveness.

The advantage of the theoretic approach presented in the article is its possibility to be used for analysis and development of the effective strategy of administration of informational interaction between authorities and business entities and public with the use of cutting-edge technology of Big Data processing and analysis.

\section{REFERENCES}

11] Baburin V.A., Yanenko M.E. "Big Data technologies in service: new markets, opportunities and problems," TTPS, No.1(27), pp. 100-105, 2014

[2] Bushueva L.I. "Administrative model of informational interaction between authorities and the region," Statistics in digital economy: training and use: international workshop conference (St. Petersburg, 12 February 2018). St. Petersburg: Saint Petersburg State University of Economics, p. 42-44, 2018.

[3] Debelak, D. Business model: Principles for creating a thriving organization. Trans. by I. Kovalenko. Moscow: Grebennikov, 2009. $256 \mathrm{p}$.

[4] Mayer-Schonberger V., Cukier K. Big Data: A Revolution That Will Transform How We Live, Work, and Think. Trans.from English by Inna Gaydyuk. Moscow: Mann, Ivanov and Ferber, 2014. 240 p.

[5] Osterwalder A., Pigneur Y. Business Model Generation: A Handbook for Visionaries, Game Changers, and Challengers. Trans. by Maria Kulneva. Moscow: Alpina Publisher, 2012. 288 p.

[6] Popova Yu.F. "On valuation of the effectiveness of the management of the relationships in the value chain," Corporate management and innovative development of the Northern economy: Bulletin of Research and Development Center of Corporate Law, Management and Venture Investment, Syktyvkar State University, No.1, p.35-55, 2014.

[7] Rasskazova Yu. "Big Data at Work," Information Technologies, No.1, $\begin{array}{llll}\text { p.3-4, 2015. [digital resource]. } & \text { URL: }\end{array}$ http://www.rbcplus.ru/news/555e7b397a8aa97cb615f209 (access date 10.02.2018).

[8] Amit R., Zott C. "Value creation in e-business," Strategic management journal. 2001. Vol. 22. No.6/7. P. 493-520.

[9] Big data: The next frontier for innovation, competition, and productivity. - McKinsey Global Institute, 2011. $156 \mathrm{p}$

[10] Ilin, I., Lepekhin, A., Levina, A., Iliashenko O. (2018) Analysis of Factors, Defining Software Development Approach. Advances in Intelligent Systems and Computing. Volume 692, Pages 1306-1314.

[11] Chesbrough H. "Business model innovation: it's not just about technology anymore,” Strategy \& leadership. 2007. Vol. 35. No.6. P. 12-17.

[12] Finos Ralph. Big Data Adoption Progress Across Industries. [digital resource]. URL: http://wikibon.com/big-data-adoption-progressacross-industries/ (access date: 20.02.2018).

[13] Ilin, I. V., Frolov, K. V., \& Lepekhin, A. A. (2017). From business processes model of the company to software development: MDA business extension. Paper presented at the Proceedings of the 29th International Business Information Management Association Conference - Education Excellence and Innovation Management through Vision 2020: From Regional Development Sustainability to Global Economic Growth, 1157-1164.

[14] Bozhko, Y. V., Maksimkin, A. I., Baryshev, G. K., Voronin, A. I., \& Kondratyeva, A. S. (2016) Digital transformation as the key to synthesis of educational and innovation process in the research university. Communications in Computer and Information Science

[15] Schroeck M. Analytics: The real-world use of big data / M. Schroeck, R. Shockley, Dr. Janet Smart // IBM. 2012. URL: https://www.bdvc.nl/images/Rapporten/GBE03519USEN.PDF (access date: 10.02.2018). $22 \mathrm{p}$.

[16] Shafer S., Smith H. J., Linder J. The power of businessmodels//Business horizons. 2005. Vol. 48. No.3. P. 199-207.

[17] Stewart D. W., Zhao Q. Internet marketing, business models, and public policy//Journal of public policy \& marketing. 2000. Vol. 19. No.2. P. 287-296

[18] Timmers P. Business models of electronic markets// Electronic markets. 1998. No.8. P. 3-8. 